\title{
Précis knihy Hegelova fenomenologie světa ${ }^{1}$
}

\author{
Tereza Matějčková \\ Filozofická fakulta \\ Univerzita Karlova \\ Nám. Jana Palacha 1, 11638 Praha 1 \\ Tereza.Matejckova@ff.cuni.cz
}

Pojednání shrnuje základní argumenty knihy Hegelova fenomenologie světa (2018). Autorka se připojuje $\mathrm{k}$ tradici, která jenský spis vykládá jako tzv. Bildungsroman, a na tomto pozadí osvětluje pojem světa, který jí slouží jako hermeneutický klíč celkové interpretace knihy. Proti tradičním interpretacím Fenomenologie jako „Bildungsromanu“ autorka tvrdí, že se zde „nebuduje“ vědomí, ale konkrétní forma světa. Vědomí vychází ve svém vnímání, myšlení a jednání vždy z určitého konceptu světa či světskosti. V tomto smyslu chápe autorka svět jako model skutečnosti podmiňující vědomí ve výkonu poznání i jednání. Postup Fenomenologie je vývojem, v němž se jednotlivé světy coby „konkrétní celky“, tedy modely skutečnosti, postupně hroutí, protože skutečnost nedostatečně vystihují. Tento nedostatek se typicky ohlašuje $\mathrm{v}$ zakoušených epistemologických, morálních či praktických nezdarech. Absolutní vědění je pojato jako ta úroveň, na níž se podaří formulovat svět, který skutečnosti, alespoň podle Hegelova nároku, nejlépe „odpovídá“: tento svět stojí na uznání konečnosti a plurality jakožto konstitutivních principů skutečnosti.

Klíčová slova: absolutní vědění, reflexivita, Bildungsroman, konflikt, ironie, duch, Hegel

1 Tato práce vznikla za podpory projektu „Kreativita a adaptabilita jako předpoklad úspěchu Evropy v propojeném světě“, reg. č.: CZ.02.1.01/o.o/o.o/16_019/0000734, financovaného z Evropského fondu pro regionální rozvoj. 
Seeking to conquer a larger liberty, man but extends the empire of necessity. H. Melville, Bell-Tower

\section{1 Úvod}

Záměrem knihy bylo „vysvětlit si“ Fenomenologii ducha, k níž jsem přistupovala $\mathrm{s}$ jistým údivem. Hegel bývá vykládán jako systematik a racionalista, což není překvapivé vzhledem k tomu, že svou filosofii, včetně fenomenologie, sám jako systém označuje. Navzdory tomu je v mnohých pasážích knihy, především v úseku Rozum a v centrálním úseku Duch, obtížné odhalit jakoukoli formu systematičnosti v př́ípadě, že za systematický nepovažujeme již takový text, o němž autor ujištuje, že systematický je. Ve zmíněných úsecích se čtenář setkává se směsí témat, která lze do systematického celku uvést obtížně, místy se navíc zdá, že o to Hegel ani neusiluje a vrší nesourodé motivy a témata: interpretaci Antigony, reflexi moderního tržního hospodářství, akademického provozu, Goetheova Fausta, Francouzské revoluce, teroru a fanatismu či dobové psychologie a šílenství. Celá kniha pak končí upravenou verzí cizí básně, Schillerova Přátelstuí. ${ }^{2}$

Sám Hegel se k Fenomenologii, která byla jeho první knihou v pravém smyslu slova, stavěl rezervovaně, nejspíše i z důvodu její živelnosti. $\mathrm{V}$ této slabině však můžeme spatřovat sílu: kombinace nejasnosti, snad i nepřesvědčivosti s myslitelskou velikostí nutí čtenáře, aby s Hegelem vstoupil do dialogu a spolu s ním sledoval cestu „protagonisty“ díla. Tatáž slabina se projevila v dalším působení spisu, kterému se nevyrovná vliv žádného jiného Hegelova titulu. Dokonce lze tvrdit, že samo toto působení $\mathrm{v}$ rozličných disciplínách popírá to, co je Hegelovi mnohdy vytýkáno: přepjatý, do sebe uzavřený racionalismus.

Při svém výkladu jsem vyšla z principu, že jednotlivé části nelze interpretovat nezávisle na celku knihy. Tento př́stup se zdá být

2 Samozřejmě nejsem první, kdo si všímá toho, že systematičnost zůstává na úrovni proklamace. „Standardním“ článkem zabývajícím se touto otázkou je pojednání od Roberta Pippina (1993): „You Can't Get There from Here: Transition Problems in Hegel's Phenomenology of Spirit“. 
v nějakém ohledu samozrrejmý: je dobré přečíst celou knihu, jejíž část chceme interpretovat. V případě Hegela však tento postup zcela běžný není a jeho interpreti se až příliš často omezují na jednotlivé pasáže, nejčastěji na úseky Vědomí a Sebevědomí. S ohledem na bohatost, délku i komplexnost Fenomenologie je tento př́istup legitimní. Přesto jsem pro sebe vyšla z předpokladu, že porozumět Fenomenologii není možné, pakliže nepřistoupíme na to, že je třeba přečíst knihu celou a všechny úseky v interpretaci zohlednit. Již tento krok je veden nesamozřejmým rozhodnutím: ke knize jsem přistupovala jako k románu svého druhu a ve vědomí jsem spatřovala protagonistu. Takové interpretace nejsou neobvyklé. Stačí vzpomenout na časté tvrzení, že Hegelova Fenomenologie je „Bildungsroman“, ${ }^{3}$ logicky je v tom případě důležitý začátek, konec i prostředek.

Mým cílem proto bylo najít hledisko, které by mi umožnilo interpretovat Fenomenologii jako celek. ${ }^{4}$ Východiskem se mi stal pojem světa - pojem, který sám Hegel za pojem nepovažuje. Spíše má za to, že se jedná o „představu“, navíc dost nedokonalou, a není proto pochyb o tom, že „svět“ nelze stavět naroveň pojmo̊m jako vědomí, sebevědomí, rozum nebo duch. Záměrně nehegelovská volba východiska mi umožnila získat od Hegelovy filosofie odstup. Podobně důležitou motivací bylo, že „Svět“, s nímž spojuji objev moderní společnosti, je v mém čtení čímsi, co Hegel formuloval jako první filosof, aniž by si toho byl sám plně vědom.

Nehledě na to, že formy společnosti existovaly před modernou, přichází Hegel s intuicí, že v období po Francouzské revoluci, kterou ve Fenomenologii rovněž reflektuje, se člověk i jeho svět mění mocí toho, co Hegel později nazývá „občanskou společností“. 5 Široký pojem „společnost“ není novým lidským místem uprostřed skutečnosti. Hegel jím spíše vyjadřuje náhled, že člověk získává vědomí, které dosud postrádal - nahlíží, že je schopen vytvořit něco nového, v tomto případě novou světskou strukturu, a tím proměnit skutečnost, v níž žije, i sebe sama.

3 Viz např. Hyppolite (1979, s. 11 n.); příp. Gamm (1997, s. 127).

4 Cena za celek je přirozeně nemalá. Plným právem si Martin Vrabec (2018) ve své recenzi všímá, že se kniha rozbíhá do příliš mnoha směrů a přechody nejsou vždy dobře vyznačeny.

5 Hegel (1992, § 182, s. 219): „Vytvoření občanské společnosti náleží ostatně modernímu světu, který všem určením ideje teprve poskytuje jejich právo.“ 
Člověk si je tedy nyní vědom toho, že z jeho myšlení povstává nová skutečnost svého druhu: přirozeně ne svět hor, lesů a koní, ale svět tržního hospodářství, rozvodů a subjektů práva, přičemž se k těmto fenoménům také vztahuje jakožto jím ustaveným. Člověk se tím nově vztahuje i sám k sobě: jeho povinnosti (vůči předkům, bohům a tradici), které jej dosud definovaly, jej již nepředcházejí, sám si formuluje povinnosti vlastní. Toto heroické ocenění člověka, který ustavuje jakýsi nový svět, je však ambivalentní, o čemž svědčí, že vědomí této nově nabyté moci doprovází ironie, mnohdy vystupňovaná do nihilismu, ale i do patologií, které Hegel shrnuje pod pojmy fanatismu, teroru či šílenství. V jiných podobách se heroismus převrací do rezignace. Ambivalentní je nakonec i „absolutní vědění - to je sice často označováno za výsledek Hegelova vlastního heroického vypětí, častěji však přepětí, ve skutečnosti se v absolutním vědění neproklamuje moc jednotlivce, ale spíše specifický typ bezmoci tváří v tvář modernímu světu.

Je př́iznačné, že se Hegel pojmem světa zabývá nejexplicitněji na úrovni Rozumu, tedy na úrovni věnované moderní filosofii, především Kantovi a jeho dvěma stěžejním kritikám, Kritice čistého rozumu a Kritice soudnosti. Zároveň nelze ztratit ze zřetele, že Hegel nepíše vědecké pojednání o Kantovi, a místo toho sleduje, jaký obraz světa je zde implikován, a rovněž zohledňuje to, jak se Kantovy intuice vepsaly do dobových filosofií. Na tomto pozadí poznamenává:

„Když se [vědomí] tak chápe, je mu, jako by pro ně teprve nyní vznikal svět; dříve mu nerozumí, chová se k němu žádostivě a zpracovává jej, stahuje se ze světa do sebe a vydává jej pro sebe zkáze, jakož i sebe jako vědomí - vědomí světa jako bytnosti i vědomí jeho nicoty. Teprve takto, když bylo ztratilo hrob své pravdy a vydalo zkáze zkázu své skutečnosti a když jednotlivé vědomí mu platí za absolutní skutečnost o sobě, objevuje se svět jako svioij nový skutečný svět, o nějž má zájem v jeho trvání jako předtím jen v jeho zániku; nebot jeho trvání se mu stává jeho vlastní pravdou a přitomností: je si jisto, že v něm bude zakoušet jen sebe.“6

6 Hegel (1960, s. 179 n.). 
Jinými slovy je Kant pro Hegela myslitelem, který učí vědomí, jak získat důvěru v sebe sama jakožto konečnou bytost i jak získat důvěru $\mathrm{v}$ př́tomný svět, nebot' ten je jediný, který můžeme poznávat. Proto je také legitimní, že sem směřuje náš zájem. Vědomí navíc nyní zjištuje, že právě v tomto světě (nikoli v zásvětí či při posledním soudu) jsme svědky i původci rozhodujících událostí.

V Hegelově čtení má vědomí zprvu tendenci chápat tento svět po vzoru moderních vědeckých modelů a moderní vědy rovněž vydávat za vzor filosofie. Proto je moderní model světa původně světem přírody a jejích zákonů, což dojde tak daleko, že se samo vědomí, vědomo si toho, že je součástí světa pojatého jako příroda, identifikuje s kusem přírody, konkrétně se svým tělem: „Skutečnost a jsoucno člověka je lebeční kost.“7

U této identifikace však nesetrvá dlouho. Skutečnost, že je takovou kostí, která o sobě reflektuje, vede vědomí $\mathrm{k}$ náhledu, že jeho pravou podstatou je schopnost vymanit se z prŕrodovědných zákonů a, kantovsky řečeno, iniciovat novou řadu jednání. $V$ těchto pasážích se proto udává jeden z nejpodstatnějších zvratů Fenomenologie. Vědomí seznává, žejeho svět není světem předmětů ani fyzikálních či přírodovědných zákonů, ale světem jednání, a čtenář tak spolu s vědomím zakouší jakýsi „literárni““ obrat. K porozumění sebe, druhých i skutečnosti již neslouží př́rodní věda ani fyzikální zákony, ale literární díla, v nichž autoři studují jednání a s ním spjaté krize, konflikty, provinění i smíření.

\section{Svět a světskost v úvodu Fenomenologie}

Vúvodu Hegel definuje vědomí jako dynamiku, která si je vědoma zároveň sebe sama a svého předmětu, resp. je sám předmět „př́ležitosti““ pro vlastní zvědomění. „Nebot' vědomí je jednak vědomí předmětu, jednak vědomí sebe sama: vědomí toho, co je pro ně pravdivé, a vědomí svého vědění o tom." ${ }^{8}$ Podstatný je Hegelův vhled, že vědomí vždy vnímá více, než si je vědomo, že vnímá. Již na první úrovni nahlíží, že není schopno vnímat jednotlivé předměty nezávisle na kontextu. Tento kontext však není dalším souborem věcí: do zkušeností, které jsou vždy zkušenosti

7 Tamtéž, s. 233.

8 Tamtéž, s. 101. 
se světem, vstupuje jazyk a schopnost sdělit druhému, co vidí nebo co vnímá, a poznání tak není nikdy zcela odloučeno od vztahu k druhému člověku, před nímž jej zdůvodňuje a na němž si jej i „testuje“.

Tato okolnost je podstatná ve dvou ohledech. Vědomí, které vnímá nevyhnutelně více, než explicitně vnímá, a které tudíž nezakouší jednotliviny nezávisle na kontextu, činí zkušenosti, které chci označit jako „substanční“. To znamená, že jsou vždy zprostředkované jazykem, kulturou a vztahy $\mathrm{k}$ druhým. Nechci tím říct nic více, než že Hegel formuluje určitou podobu holismu, resp. přesvědčení, že vědomí již vždy žije v konkrétní podobě omezeného „celku“. O tom, že je tento celek vždy omezený, svědčí cesta Fenomenologie. Vědomí formuluje na každé úrovni konkrétní celek, což znamená, že vychází na každé úrovni z (často nevědomé) koncepce toho, co je pro něho bytí, jak rozumět skutečnosti a co jsou jeho hlavní orientační body pro porozumění sebe sama, druhých a svého světa. Vědomí tak sice žije v jednotlivosti, ale na každé úrovni formuluje svou koncepci toho, co je pro ně celek. Právě tuto koncepci jsem nazvala „světem“.

Svět je modelem skutečnosti a vědomí si na každé úrovni tvoří „plánek skutečnosti“. Rovněž na každé úrovni se ukazuje, že plánky musí být přepracovány, nebot’ představa o tom, co je skutečné, se pokaždé rozchází s tím, co je skutečně skutečné. K nutnosti přepracovat svo̊j návrh přitom vědomí nedospívá v hlubokém zamyšlení či v obratu do nitra. Spíše se mu svět, na němž se spolupodílel svými představami o něm, pokaždé stává neudržitelným, nejčastěji z důvodu neřešitelných konfliktů s druhými. Na pozadí toho, že Hegela máme tendenci číst jako myslitele smíření, stojí za povšimnutí, že Fenomenologie je sérií konflikto̊, které se neřeší, ale opouští. Problém totiž nelze vyřešit ve světě, jehož principy k danému konfliktu směřovaly, ale ve světě novém, který následuje po zhroucení světa starého.

Světu tak rozumím jako rovině objektivity, kterou formuluje vědomí a která nemůže být redukována na subjektivitu, na bytí pro sebe; zároveň je tato rovina skutečnosti dána jedině skrze bytí pro sebe, skrze vědomí. Fenomenologie je pak „cestou“, která „obsáhne pohybem svého pojmu úplný svět vědomí $v$ jeho nutnosti“ ${ }^{9}$ Přirozeně bude pro porozumění 
tohoto pohybu stěžejní Hegelova dialektika - v mém čtení vstupuje do vztahu vědomí ke svému světu: vědomí svět zčásti konstituuje, zčásti jej nachází v sobě, ale snad ještě podstatnější je, že se má ve světě nacházet. Základním omylem, s nímž se vědomí potýká, je, že jakožto jednotlivec vyhlásí panství nad světem, tedy že vznese příliš bezprostřední nárok na svưj svět. Hegel formuluje nejen napříč Fenomenologií, ale celým svým dílem základní vhled, že člověk je člověkem mezi druhými, tedy ve sdíleném světě, což má aspekt nepochybně i etický, v první řadě však epistemologický: nezávisle na druhém jsme neschopni poznávat, samy duchovní schopnosti navíc vznikají z koordinace s druhými.

Podstatnýjeještějeden ohled. Hegel opakovanězdůrazňuje, především ve svém Úvodu, že svět je skutečností, ve prospěch níž se máme zcizovat či zbavovat se tu své sebelásky, tu marnivosti či zpupnosti. ${ }^{10}$ Zároveň však platí, že pokusy o správné vystižení skutečnosti v podobě jednotlivých modelů světa se nevyčerpávají v pouhém kopírování, ale samy jsou utvářením (Bildung), a to nejen vědomí, ale především skutečnosti.

Co se tím míní? Než tuto souvislost osvětlím, je třeba zdůraznit, že každé vědomí, které usiluje o sebepoznání, zároveň usiluje o svobodu. Z úsilí o vypracování obrazu světa, v němž se vědomí může najít, vzniká nový typ skutečnosti, resp. vědomí si uvědomuje, že svým uchopováním do skutečnosti vstupuje a samu ji proměňuje, a že tak není podrobeno jako Antigona, jedna z prominentních protagonistek Fenomenologie, věčným zákonům, ale zákonům, které, lakonicky řečeno, formulují volení zákonodárci. Vzniká tak svět, v němž je vědomí vedeno k náhledu, že je spolutvưrcem své skutečnosti, a díky tomu je schopno v závěru knihy formulovat poslední model světa, který nevede ke konfliktům se skutečností: je to svět subjektivních práv a uznání konečnosti, svět, v němž vědomí nahlíží, že to, co z vědomí vychází, na něj zpět dopadá.

V závěru se tak ocitáme ve světě, který se sám vyznačuje reflexivitou a který je světem konkrétního období, Jeny roku 1806, tedy doby a místa, kde myslitelé formulovali reflexivitu lidského ducha i jeho světa, který člověku odpovídá. ${ }^{11}$ Právě toto „odpovídání“ světa a vědomí

10 Tamtéž, s. 100 aj.

11 Nutno přirozeně zdůraznit, že Hegel sám si byl vědom tohoto historického podmínění, zároveň však nepochybně vznášel nárok na tvrzení, že objev této sebereflexivity je objevem překračujícím každou historickou epochu, nebot' vyjadřuje, konečně, pravdu ducha vůbec. 
je nyní oslavováno jako uskutečnění svobody: člověk vstupuje do světa, kterému se podřizuje, ale může jej rovněž v úsilí s druhými ovlivňovat a spoluvytvářet. Je pozoruhodné, že tento fakt - že vstupujeme do světa i do př́rody - dnes již nechápeme jako výraz svobody, ale prokletí: jsme zavěšeni (ne-li oběšeni) na našich konstrukcích a příroda na naše zásahy odpovídá způsobem, který se jeví jako fatální.

Podobně jako v Hegelově post-revolučním období ožívá i dnes snaha formulovat nový svět, v němž by člověk mohl žít, aniž by byl ve sporu se skutečností.Znovu tak vidíme, že rovnice, z níž vycházíme, nemá dvěstrany, ale vlastně tři: jednou je člověk, druhou je skutečnost a třetí svět jako obraz skutečnosti. Hegel měl snad skutečně za to, že svět, který byl v moderně zformulován, je světem, který skutečnosti dokonale odpovídá, a možná, že to nebyl jen jeho „výmysl“, ale že byl prodchnut „duchem doby“. Jak víme, duch doby se záhy proměnil. Další myslitelé přitom nezpochybnili zvláštní souvislost člověka, moderny a nového „světadílu“ - společnosti -, měli však za to, že tato souvislost může být fatální. Zatímco tak Hegel mluví o zrcadlení, pracuje Nietzsche s jinou metaforou: člověk a skutečnost si v moderním světě neodpovídají, ale spíše se vzájemně kamenujíi. ${ }^{12}$

\section{Modely světů}

\subsection{Vědomí: svět jako sada předmětů}

Jednotlivé světy je možné schematizovat podle mohutností, které jsou osou celé knihy. Na úrovni Vědomí, tedy v kapitolách a) Smyslová jistota čili „toto“ a mínění, b) Vněm anebo věc a klam a c) Síla a schopnost rozvažovat, zjev a nadsmyslový svět, usiluje protagonista o porozumění své skutečnosti tím, že formuluje cosi jako realistickou ontologii. To, co je, jsou jednotlivé věci a základním prostředkem k jejich porozumění je vnímání, do něhož, pro protagonistu samého nepozorovaně, promlouvá myšlení. ${ }^{13}$

12 Nietzsche (2018, s. 281): „Ó Zarathustro, ty kameni moudrosti, kameni hozený z praku, ty drtiteli hvězd! Sám sebe jsi tak vysoko vymrštil, ale každý vymrštěný kámen - spadne! Odsouzen k sobě sám a k vlastnímu kamenování: ó Zarathustro, vskutku, daleko jsi vymrštil kámen - ale na tebe spadne zpět!“

13 Myšlení podrobuje Hegel explicitnímu zkoumání teprve v kapitole Sebevědomí. Příznačný je zde praktický obrat: člověk se naučí myslet teprve poté, co se naučil pracovat: myšlení poznává to, co člověk vytváří. Viz Hegel (1960, s. 162 n.). 
Vědomí je na první úrovni přesvědčeno o receptivnosti poznávání, a je si jisté pouze tím, co vnímá tehdy, nechá-li na sebe působit bohatství smyslových vjemů. To je ostatně důvod, proč se jedná o jednu z „němých“ úrovní. Jazyk by do dané situace vnesl zprostředkování, které poznávající nepovažuje za slučitelné s jistotou. V kapitole Síla a schopnost rozvažovat, zjev a nadsmyslový svět přechází vědomí $\mathrm{k}$ abstrakci. Nadále vychází z vnímání, předměty však nyní uchopuje prostřednictvím fyzikálních zákonů. Vycházejíc z fyzikálních zákonů formuluje „zásvětní říši“, která je „neviditelnou“ pravdou smyslových věcí. Vědomí se přitom dopouští chyby, která se bude opakovat. Fyzikální zákony, které jsou modely skutečnosti, zaměňuje se skutečností samou, a tedy zapomíná, že tyto zákony formuluje $\mathrm{s}$ ohledem na poznání jednotlivin, nikoli zákonů samých. Fascinace „klidnými“ zákony nadsmyslového světa vede vědomí $\mathrm{k}$ tomu, že je prohlásí za pravý původ smyslové skutečnosti. „V této vnitřní pravdě... otvírá se teprve nad světem smyslovým jakožto světem zjevu nyní svět nadsmyslný jakožto pravý svět, nad zanikajícím tímto světem trvalý onen svět. “"14

Vědomí tím dospívá $\mathrm{k}$ jednomu $\mathrm{z}$ nejzákladnějších modelů skutečnosti: podstatou, počátkem či východiskem (Grund) skutečnosti je identita vyznačující se stálostí, sekundární je mnohost a časovost. $\mathrm{V}$ předložené koncepci vládne tento model základním metafyzickým i teologickým přístupům ke skutečnosti, a Hegel tak vlastně ukazuje, že se jedná o svod v samém myšlení, a tento model tak sehrává stěžejní roli na každé úrovni Fenomenologie. V závěru tohoto úseku je vystupňován do absurdní koncepce tzv. převráceného světa: to, co je v př́tomném světě pohyblivé, je ve skutečnosti, tedy v „pokojném“ zásvětí, nehybné a stálé. Následně aplikuje tento vhled i na praktickou sféru: to, co je ve světě přítomném považováno za hanebné, bude $\mathrm{v}$ zásvětní skutečnosti chváleno, a naopak. Vědomí tím formuluje hermeneutický klíč, který sice nesezná jako nepravdivý, který však vzápětí přesto odmítne. Hroutí se tak první model skutečnosti, který v sobě zahrnoval hned tři světy: první smyslový, druhý nadsmyslový a třetí převrácený.

Důvod, proč vědomí tento pohled na svět opouští, netkví ani tak $\mathrm{v}$ tom, že by se jednalo o model, který by v nějakém ohledu nebyl nosný.

14 Tamtéž, s. 131. 
Na takovém přehodnocení jsou založeny mnohé náboženské představy, nakonec i ta podle Hegela nejpodstatnější: zkáza v sobě nese největší příslib. Problém tedy tkví v něčem jiném. Předložený klíč neumožňuje náležitě číst přítomnost $\mathrm{v}$ jejím přítomném zakoušení, a neumožňuje tak vědomí, aby zůstalo „věrno fenoménům“, což je však podmínka, aby vědomí mohlo působit $\mathrm{v}$ př́tomném světě.

$\mathrm{V}$ závěru kapitoly vědomí rezignuje na rozdělení skutečnosti na dvě (či spíše třii) sféry, aniž by se přitom vzdalo získaných pojmových prostředků. Místo toho, aby dělilo opozita na dva světy a kladlo proti pravdivému světu pravdy a stálosti svět klamný a pohyblivý, formuluje stanovisko, dle kterého leží pravda zkušenosti v samé zkušenosti, v níž se opozita konstituují ze sebe navzájem. Spolu s tím formuluje i nový koncept vnímání: věci nevnímáme jako do sebe uzavřené, se sebou identické podstaty. Jakožto vnímané jsou pro nás spíše vztahy, a to proto, že vnímání není ve svém výkonu „sčítáním“ jednotlivých počitků; spíše je rozlišováním a formulováním rozdílů. Lakonicky řečeno, svět povstává ne tím, že sčítáme, ale tím, že škrtáme. Proto může Hegel označit věc či předmět jako „vnitřní rozdíl““ ${ }^{15}$ Fenomén tak není ničím substanciálním, ale rozdílem vystupujícím díky vědomí z konkrétního pozadí.

\subsection{Sebevědomí: svět konfliktů a bojů}

Vhled, že podstata skutečnosti netkví v substancích, ale v relacích, vede sebevědomí k formulování dialektiky, která je „jednoduchou bytností života, duší světa“ ${ }^{16}$ Skutečnost nyní „„žívá“. Zatímco vědomí mělo za to, že zformuluje nejvěrnější obraz skutečnosti tehdy, bude-li skutečnosti „nejblíže“, a vzdá-li se tedy zprostředkování, je s pojmem života spjato uvědomění si sebe sama. Skutečnost sama je vztahem, a to vztahem sebevědomí a svého vnějšku. Tento model skutečnosti tak nevychází z předmětnosti, ale ze subjektivity, resp. z intencionality vědomí, které si je nyní vědomo své konstitutivní moci.

Moc a násilí nyní vstupují do děje Fenomenologie: sebevědomí je přesvědčeno, že pravda musí být vydobyta a ke skutečnosti se vztahuje

15 Tamtéž, s. 142.

16 Tamtéž. 
„stravujícím“ způsobem. Tomu odpovídá základní princip tohoto světa: je jím boj, a právě zde čteme pasáže o boji na život a smrt, který rozpoutá sebevědomí tváří v tvář druhému sebevědomí. Konstitutivními prvky tohoto světa je tedy intersubjektivita, vzájemné uznání (a zneuznání), a svět tak na sebe bere lidskou podobu. Již není prostorem věcí a fyzikálních zákonů; sebevědomí má za to, že odhalilo základnější rovinu, kterou je vztah a spolu s ním i napětí, konflikt a bolest.

Model skutečnosti se tak nyní ukazuje být světem, jehož těžištěm je sebevědomí, které se samo sebou stává na cestě omylů, proher a selhání. Tento vhled nepozbyde platnost: jakmile se protagonista stává sebevědomím, vždy jej bude doprovázet určitá podoba neštěstí, které je zároveň možností situaci změnit, a je tak výrazem bytostné souvislosti vědomí a negativity. Proto se také opakovaně vyjevuje tendence známá z úrovně Vědomí: vědomí se jen velmi obtížně vzdává představy, že by mohly existovat světy bez negativity a utrpení, a tak formuluje nové podoby zásvětních světů.

$\mathrm{Na}$ úrovni Sebevědomí je tato zásvětní skutečnost vykreslena v explicitně náboženském jazyce. Jakmile je ale jednou ustavena, opakuje se „scénář“ $\mathrm{z}$ předešlé úrovně: sebevědomí nahlédne, že takzvaný „onen svět“ je pro ně neobyvatelný, a to proto, že je neslučitelný se sebevědomím, které je bytostně konečným a omylným, ale které je rovněž konstitutivním momentem skutečnosti. I na této úrovni se sebevědomí vrací do vezdejšího světa, a zatímco tak vědomí nakonec objevuje „duši světa“v podobě dialektiky, sebevědomí formuluje koncept smíření: přijímá bolest a utrpení pramenící z chyb jako význačný pramen zkušenosti, jako podmínku pravdy. Pravda není navzdory omylu; je opraveným omylem, a tak neexistuje nezávisle na lži, chybě i ublížení druhému. Jinými slovy neexistuje žádná původní bezprostřední pravda, existuje jen původní omyl.

\subsection{Rozum: svět zákonů}

Úroveň Rozumu se zprvu vyznačuje tím, že vědomí „dospělo“, skoro jako by odložilo nesvéprávnost, kterou mu Kant vytýkal. Již nevisí dětinsky na své partikularitě ani adolescentně „nepřežvýkává“ své bolesti 
a křivdy. Nyní je přesvědčeno, že je schopno uchopit skutečnost z ní samé, aniž by přitom propadalo iluzi prvního stupně, tedy představě, že pochopení je podmíněno pasivním, pouze registrujícím postojem. Nyní se zdá být zjevné, že subjektivita je součástí skutečnosti, nikoli však v podobě individuální rozumnosti, ale rozumnosti obecné. Vědomí tak nachází novou pozici ve formulování zákonů, které již nejsou fyzikální, ale apriorní povahy, a formuluje tak transcendentální rámec, který nese podobnosti s Kantovými kategoriemi.

S pozicí Kanta první kritiky se však vědomí nespokojuje a od transcendentálních zákonů přechází ke snaze formulovat obecné zákonitosti v empirické skutečnosti. Chce tím ukázat, že skutečnost sama je racionální, dokonce že sebevědomí a předmětná skutečnost jsou sjednoceny jednou jedinou racionalitou. Pravdou skutečnosti tak nyní nejsou jen zákony transcendentální, ale i přírodovědné a fyziologické. Vědomí nadané rozumem nyní $\mathrm{v}$ jednotlivém formuluje obecné a v nahodilém nutné, a tím se ustavuje jako hlavní hermeneut toho, co v pravdě je.

Když shledává, že je sice schopno ke každé nahodilé jednotlivosti zformulovat více či méně obecný, více či méně pravděpodobný zákon, začíná si uvědomovat, že jen „převypravuje skutečnost“, že ji vlastně reprodukuje na vyšší úrovni. Sám o sobě může být tento postup cenný, problém je, že vědomí, které jednou nahlédlo, že je sebevědomím, ví, že rozumového tvora nevystihuje nejlépe to, že myslí, ale že jedná: člověk je řadou svých činů. Nakonec nelze právě ani člověka samého uchopit obecnými kategoriemi. Specifická je pro něho konkrétnost, která je spjata se schopností nepředvídatelné reakce.

Vědomí se tak přivrací k primátu praktična, aniž by přestalo být rozumem - že je nadále rozumem, znamená, že je puzeno k formulování obecnosti, např. kategorického imperativu, „zákonu srdce“ či svědomí. Znovu se ukazuje, že rozum je „vyladěn“ na vyšší oktávu, a myšlení se tak vyznačuje tím, že se nezabývá jednotlivostí, ale její podstatou, původem či zákonem.

Svět pojatý jako souvislost teoretických a praktických zákonů se nakonec ukazuje jako neuspokojivý proto, že skutečnost není jen myšlením. Myslet jsme schopni jen díky tomu, že existuje vždy více než 
myšlení. Vědomí proto nyní přechází na úroveň Ducha, kde se ocitá v „podobách světů“: ${ }^{17}$ setkáváme se zde s nahodilými zvraty, které nelze dedukovat, ale jen zpětně rekonstruovat, s jednotlivinami, jejichž individualitu nelze postihnout, a s marnými pokusy o uchopení logické struktury v tom, co se myšlení vzpírá.

\section{Duchovní podoby světa}

Ve schematické podobě jsou na úrovni Ducha vytyčeny dva hlavní světy: svět antického Řecka a svět moderní německý. Ten řecký je definován nadvládou „věčných zákonů“; je to svět odvozený od bohů a tradice. Člověka v tomto „substanciálním“ světě povinnosti předcházejí, naopak v moderním světě jej následují, nebot’ si je sám formuluje. Do dynamiky vzájemného uznání, které protagonista objevil na úrovni Sebevědomí a které se nyní stává základem moderního světa, je včleňován stále větší podíl toho, co dosud platilo jako dané. Zjednodušeně řečeno to znamená, že obyvatel moderního světa je ochoten se identifikovat jen s tím, co tváří v tvář druhému může věrohodně obhájit, což v tomto kontextu znamená racionálně zdůvodnit. Vše to, co před druhým nelze zdůvodnit, musí zůstat před branami moderního světa a jeho norem.

$\mathrm{Z}$ tohoto vhledu povstává svět, $\mathrm{k}$ němuž Hegel vztahuje pojem „absolutní vědění“. Toto vědění není typem vědomí a rovněž je nelze připsat žádnému jednotlivci. Vědomí na úrovni Absolutního vědění formuluje vhled, že svět je společností, která podléhá zákonitostem, které formuluje samo vědomí. Hegel si však nevšímá jen vzniku společnosti, ale rovněž toho, že spolu s moderní společností vzniká něco dalšího: odcizení. Moderní vědomí, které ví, že formuluje základy svého světa, je ze všech podob vědomí to, které je ve svém světě nejméně zabydlené. Problém odcizení tak vzniká teprve ve světě, na nějž vznášíme nárok, abychom se v něm poznali, což je něco, co antický člověk od svého světa neočekával.

17 Tamtéž, s. 289: „Duch je mravní život národa, pokud je bezprostřední pravdou - je individuum, které je světem. Od toho, čím je bezprostředně, musí přejít k vědomí, musí zrušit krásný mravní život a dospět řadou podob $\mathrm{k}$ vědění sebe sama. Tyto podoby se však liší od předchozích tím, že jsou to duchovní reality, vlastní skutečnosti, a místo aby byly pouze podobami vědomí, že jsou to podoby světa.“ 
Specifikem této koncepce odcizení je, že se nejedná o fenomén, který lze překonat, dokonce můžeme tvrdit, že Hegel s ním spojuje vysloveně pozitivní rysy. Člověk formuluje zákony, k nimž se následně vztahuje jako k čemusi danému. Tento zcizující efekt mu umožňuje vytvořit substancialitu uprostřed subjektivity, a to proto, že jedině substancialita, nikoli subjektivita, může být domovem, jakkoli nedokonalým.

Tím se ocitáme v základu dalšího problému. Na úrovni Absolutního vědění člověk zjištuje, že se ocitá na obou stranách rovnice: je součástí skutečnosti i jejím autorem. Díky tomu se mu nyní daří formulovat pravdivý svět, který spadá v jedno se skutečností, anebo tento nárok alespoň vznáší. Že je tento svět pravdivý, znamená, že vědomí může být v takové skutečnosti svobodné, čímž Hegel míní, že může určovat sebe sama v základních potřebách svého života, veřejného i osobního. Přestože Hegel napříč Fenomenologiź tento aspekt svobody zdůrazňuje, s ohledem na toto jenské dílo se lze opřít ještě o jeden pro Hegela stěžejní výměr svobody: o aristotelský pojem „myšlení myšlení“. Ačkoli se Hegel o tuto podobu reflexivity zajímá i v kontextu Aristotelova díla, v mém čtení nabývá značně nearistotelské podoby. Na úrovni Absolutního vědění si je vědomí vědomo, že se nevztahuje ani ke svému osobnímu myšlení ani k myšlení vưbec; myslí myšlení druhých tak, jakje ztělesněno do moderních institucí, zvyků a mravi̊.

Tato podoba absolutního myšlení souvisí ještě s jedním Hegelovým vhledem, který v jeho díle nacházím. Myslíme jen to, co druhými již bylo myšleno. Tuto okolnost lze výstižně ilustrovat současností: co je svět, víme díky médiím. Svět myslíme tak, jak již byl někým myšlen, a díky tomu, že již někým myšlen byl, jej můžeme myslet my. Myšlení je v tomto smyslu opakováním již myšleného.

\section{Závěr}

„Z kalicha té ř́íše duchů kypí vlastní nekonečnost jemu vstříc“"18 - Hegel v závěru své knihy formuluje cosi, co můžeme označit jako ontologické oslabení skutečnosti: Nekonečnost kypí z duchů, což v mém čtení znamená: z mnohých konečných vědomí. „Ontologickým oslabením“ 
míním, že svět nyní spočívá na dynamice vzájemného uznání, na lidském konsensu a lidských roztržkách, nikoli na božích zákonech. Vyrůstá nikoli ze síly původního stvořitele či, metafyzicky řečeno, z první identity, která by postupně sestupovala do ontologicky nižší a klamavější skutečnosti. Je tomu naopak: závaznost, substancialita a normativita vyrůstá z mnohosti, od níž se nikdy zcela neemancipuje, a proto se bude vždy jednat o normativitu relativní (paradoxně vystavenou na absolutním vědění).

Hegelův pojem ducha je pravým výrazem tohoto ontologického oslabení. Znovu je podstatný zřetel svobody: jen v takto „slabé“ skutečnosti může být člověk svoboden. Vstupuje sem však rovněž jedno „ale“, které rozpracují marxisté i existencialisté a které vrhá pochybnosti na koncepci Fenomenologie jako „Bildungsroman“. To, co se napříč dílem utváří, není vědomí, ale moderní svět, který povstává ze systematického oslabování autority tradice, bohů či Boha a předků. Vědomí však nepovstává. Spíše je vyháněno ze všech jistot a nakonec seznává, že sice spolukonstituuje svět, ale tohoto světa samého není coby individuum účastno. Svět sestává z myšlení, z komunikace, avšak ani na úrovni Absolutního vědění neztrácí jednotlivec nic ze své smyslové bezprostřednosti, je to nadále tvor smyslový, cítící a tělesně žijící, tvor, který je schopen negativity, tedy schopnosti odmítnout nejen tradici, bohy a předky, ale který je schopen odmítnout i společenské normy a společenskou dynamiku moderního světa, tvor, který je vždy schopen druhému odepřít uznání.

$\mathrm{V}$ tomto smyslu je moderní svět světem, jehož vědomí jakožto individuální není součástí, a v němž proto bude vždy zakoušet určitou podobu odcizení. Toto odcizení je bytostným a nepominutelným rozměrem moderní svobody. Když proto Kierkegaard tvrdí, že myslitelé jako Hegel staví krásné budovy systémů, zatímco sami žijí v psích boudách, ${ }^{19}$ a svou filosofií vyzývá k opuštění tohoto stanoviska, odpovídá Hegel, že to není možné, protože individuum by pak svobodu, o niž od počátku šlo, nezískalo, ale pozbylo.

Vědomí se tak nakonec ocitá ve světě, jehož může být součástí jakožto osoba, objevená individualita však zůstává „za branami“. Tatáž

19 Kierkegaard (1993, s. 149). 
individualita je stálým pramenem bolesti, nebot’ nemůže být sdílena, jenže právě proto je rovněž zdrojem svobody, kreativity a vývoje. Je-li pravda, že Hegel chtěl ve Fenomenologï formulovat završení vztahu vědomí a skutečnosti, a přidržím-li se navržené trojčlenné relace vědomí - skutečnost - svět jako model skutečnosti, pak by to znamenalo, že v závěru své knihy našel způsob, jak vystihnout skutečnost způsobem, který redukoval relaci na dvojčlennou: vědomí by čelilo pravému světu.

Ale kde zůstane skutečnost? Výše jsem zmínila, že ta by se zcela vyjádřila v pravdivém světě. Co když je ale vše ještě ironičtější? Co když skutečnost nyní nespadá v jedno s „pravým světem“, ale s oním decimovaným vědomím, které bylo vehnáno do své negativity? Možná se jedná o interpretační přetížení textu, a navíc o př́liš existencialistickou interpretaci. Ale jak jinak interpretovat ono „z kalicha té říše duchů kypí vlastní nekonečnost jemu vstříc“? To, co zde „kypí“, je, zdá se, konečnost (v níž však duch nachází svou nekonečnost), a co je činné, to je skutečné.

\section{Literatura}

Gamm, G. (1997): Der Deutsche Idealismus. Eine Einführung in die Philosophie von Fichte, Hegel und Schelling. Reclam, Stuttgart.

Hegel, G. W. F. (1960): Fenomenologie ducha. Přeložil J. Patočka. Academia, Praha.

Hegel, G. W. F. (1992): Základy filosofie práva. Přeložil J. Kudrna. Academia, Praha.

Hyppolite, J. (1979): Genesis and Structure of Hegel's Phenomenology of Spirit. Northwestern University Press, Evanston.

Kierkegaard, S. (1993): Nemoc k smrti. Přeložila M. Mikulová-Thulstrupová. Svoboda - Libertas, Praha.

Melville, H. (1987): „The Bell-Tower.“ In Piazza Tales and Other Prose Pieces, vol. 9., ed. H. Hayford. Northwestern University Press, Evanston, Chicago, s. 174-191.

Nietzsche, F. (2018): Tak pravil Zarathustra. Přeložil O. Fischer. Rybka, Praha. 
Pippin, R. (1993): „You Can’t Get There from Here: Transition Problems in Hegel's Phenomenology of Spirit." In The Cambridge Companion to Hegel, ed. F. Beiser. Cambridge University Press, Cambridge, s. 52-85.

Vrabec, M. (2018): „Recenze knihy Gibt es eine Welt in Hegels Phänomenologie des Geistes?" Reflexe (55): 167-173.

\section{Abstract \\ Summary of Hegel's Phenomenology of World}

The author presents key arguments advanced in her book Hegel's Phenomenology of the World (2018). From the outset, the author accepts the hypothesis that the Phenomenology can be read as a Bildungsroman. Yet, against traditional interpretations, she avers that it is not the consciousness that "builds itself up"; instead, the reader witnesses a gradual crystallization of a specific world-order. The author argues that the consciousness senses, thinks and acts based on an implicit understanding of what the "world" is. For the author, the world designates a "concrete whole," a "model of reality" that conditions individual acts of consciousness. Consequently, the path of the Phenomenology of Spirit is read as a sequence of world-pictures, most of which are found to be deficient, i.e., they capture reality insufficiently, and thus they disintegrate. This worldly disintegration makes itself manifest in epistemological, moral, or practical failures. Absolute knowledge is a level of knowing that leads to such a conception of a world that captures reality in the most appropriate manner. This world, based on the recognition of finitude and plurality as constitutive principles of reality, can be considered the world of the modern society.

Key words: absolute knowledge, reflexivity, Bildungsroman, conflict, irony, spirit

Matějčková, T. (2020): „Précis knihy Hegelova fenomenologie světa.“ Fỉlosofie dnes 12 (1): 3-19 Dostupné z www.filosofiednes.ff.uhk.cz 